\title{
IMPAIRMENT OF ERECTION AFTER EXTERNAL SPHINCTER RESECTION
}

\author{
By P. Dollfus, F. Jurascheck, G. Adli and A. Chapuis \\ Mulhouse (France)
}

SINCE the first report in 1958 of Ross, Gibbon and Damanski on the resection of the external sphincter in the paraplegic, many other reports concerning external sphincterotomy, either by section or resection, with or without bladder-neck transurethral resection, have been published. Only very recently has there been reports on the effect of external sphincterotomy on impairment or loss of reflex erectile activity in spinal cord lesions (Rossier \& Ott, 1974: one case out of 26; Schoenfeld, Carrion \& Politano, I974: eight cases out of 25; Archimbaud, 1975: two cases out of 32 ).

\section{Methods and Material}

Since 1970 we have been using transurethral myotomy of the external sphincter associated or not with transurethral resection of the bladder neck, if needed.

Resection, which is our method of choice, is performed by one of us (F. J.) using a Wolff cutting and coagulation loop giving a $4 \mathrm{~mm}$. large and $2.5 \mathrm{~mm}$. depth trench. The aim is to perform in the first instance a minimal transurethral resection according to exhaustive clinical studies of residual urine, static and dynamic radiological examinations, completed by E.M.G. evaluation of the external sphincter.

Our approach concerning such operations has always been conservative as we do not believe that hasty urological surgery should be performed, the average period of intervention being between six and nine months after onset or accident.

Divulsion of the external sphincter has been tried out as a method for overstretching the external sphincter but only yielded temporary results.

Twenty-eight patients have been operated, Table I giving the neurological level, and 33 operations in all in this series have been performed (Table II).

\section{TABLE I}

Level of spinal cord lesions

$$
\text { Total Incomplete Complete }
$$

$\begin{array}{lrrr}\text { Cervical } & \text { 10 } & 7 & 3 \\ \text { Thoracic } & \text { I6 } & \text { I } & \text { I5 } \\ \text { Lumbar } & 2 & \text { I } & \text { I } \\ \text { Total } & 28 & 9 & 19\end{array}$


After the operation has been performed a Foley catheter $n^{\circ}$ I6 or $I 8$ F.G. is left for IO to I 2 days, bladder training beginning thereafter.

\section{Case Reports}

Case I. F. J., aged $3 \mathrm{I}$ at the time of traumatic injury in October 1970. Complete motor below $\mathrm{C}_{7}$, incomplete sensory below $\mathrm{C}_{7}$. Was operated on for the first time in June I97I. A large double (ten and two o'clock) external sphincterotomy was performed as well as a small cut in the posterior lip of the bladder neck. This operation was followed by a total loss of erection. One must add that his general status was only poor to fair and a second external sphincter resection and transurethral resection of the bladder neck was performed in October I97I with a fair result on bladder emptying. Loss of erection lasted approximately six to seven months and there was a very gradual return of reflex activity. In I975 erections are elicitable by pin-prick and touch in a very small trigger zone situated on the right side of the glans. These erections are good but last only a short time. No sexual contact has been performed since the accident. For the time being the bladder seems to be balanced with small residuals for the average capacity of $300 \mathrm{ml}$. but he still needs help from his wife. There has been a long period of sterile urine but interrupted by short lasting infections.

Case 2. A. P., aged 22 at the time of accident in October 1973. Complete sensory and motor loss below C6. First transurethral resection of the external sphincter was performed in April I974 (three and nine o'clock) and the result was unsuccessful. In October I 974 an operation aiming at total incontinence was performed by transurethral resection of the bladder neck accompanied by a resection of the external sphincter. The external sphincter resection was completed on the right side but incomplete on the left side because of a heavy haemorrhage. This last operation was followed by severe impairment (length and duration) of reflex erectile activity for seven months. This reflex erectile activity has recovered completely and on proper stimulation can last up to half an hour. Marriage is shortly to be expected! Unfortunately bladder emptying has not been satisfactory. Urine has remained infected.

A third case was considered for report with a total loss of erection activity after a transurethral resection of the bladder neck and a minimal transurethral resection of the external sphincter was performed in a man of 47 years with a very incomplete post-traumatic lesion below $\mathrm{L}_{\mathrm{I}}$. The reason is that there are definite psychological grounds for his loss of erectile activity.

\section{TABLE II}

Detail of operations performed

Divulsions

External sphincterotomies (9 resections -2 sections)

Transurethral resections of the bladder neck and transurethral resections of the external sphincter (3 with a total incontinence goal) 


\section{Discussion}

Bors (1963) and Piera (1973) have given extensive reports on the reflex erectile activity in spinal cord lesions considering the neurological aspects and treatments. It is for us difficult to say if there has been disturbances in the sacral segmental interplay resulting from such an operation, at least as the local neurovegetative system is concerned.

More likely electro-coagulation has caused a vascular lesion of the vessels involved in erection, not only in the immediate vicinity but to a depth which cannot be really estimated.

We are in agreement with Schoenfeld and others that the coagulation effects may reach nearby erectile tissues of the corpus spongiosum. In both cases reported here there have been haemorrhages and the resection trench had to be carried out as low as possible.

Our suggestion is that in such cases of proved loss of erection possibilities after a sphincterotomy a hypogastric arteriographic study of the dorsal vein of the penis should be performed to try and ascertain the integrity of the vascularity.

In our opinion there has been no correlation between the filling and the emptying of the bladder and erectile activities. Neither do we think that antispasmodic drugs did interfere with these patients, as good erections were performed under these drugs (Valium and Lioresal).

The general condition could have been a depression factor, but only after the operation, as well as the lasting infections of the urine postoperatively.

Psychological factors may have something to do with the facilitation of reflex erectile activity even in patients with a clinical lesion above Tro level but this is only a hypothesis.

\section{SUMMARY}

Two cases of temporary loss of reflex erectile activity after transurethral bladder-neck and external sphincter resection are reported in two tetraplegics.

Only recently such occurrences have been reported in the literature associated with external sphincterotomy.

The reasons are discussed and most likely direct damage to erectile tissues is the cause of such a complication.

\section{RÉSUMÉ}

Deux cas de perte temporaire de l'activité érectile réflexe chez deux tétraplégiques, après résection du col et du sphincter externe, sont rapportés.

Une telle complication n'a été que récemment mentionnée dans la littérature en association avec une sphinctérotomie externe.

Les raisons sont discutées et il est plus que probable qu'il s'agisse d'une atteinte directe des tissus érectiles au cours de l'opération.

\section{ZUSAMMENFASSUNG}

Es wurden zwei Fälle von vorübergehenden Verlust der Erektilen Reflex Aktivität bei Tetraplegiker nach Blasenhals und Sphinkterotomie, berichtet.

Eine solche Komplikation war nur kürzlich in der Literatur erwähnt in Verbindung mit einer Externus Sphinkterotomie. 
Man diskutiert die Gründe und es scheint mehr als vermutlich, dass es sich um eine direkte Läsion der Schwellgewebe während der Operation handelt.

\section{REFERENCES}

Archimbaud, J. P. (I975). Personal communication.

Bors, E. (1963). Spinal Injuries, Royal College of Surgeons of Edinburgh, 70-79.

PIERA, J. B. (I973). The establishment of a prognosis for genito-sexual function in the paraplegic and tetraplegic male. Paraplegia, 10, 271-278.

Ross, J. C., Gibbon, N. O. K. \& Damanski, M. (1958). British fournal of Urology, 30, 204-2I2.

Rossier, A. B. \& OTT, R. (1974). Urinary manometry in spinal cord injury: a follow-up study. Value of cysto-sphincterometrography as an indication for sphincterotomy. British fournal of Urology, 46, 439-448.

Schoenfeld, L., Carrion, H. M. \& Politano, V. A. (I974). Urology, IV, 68I-685.

\section{Discussion}

Mr. J. Cosbie Ross (Chairman). We have now available 20 minutes for discussion. I think it was Dr. Talbot who said that when the experts on paraplegia attain perfection there wouldn't be any need for orthopaedic surgeons or neurologists or plastic surgeons. That state of grace has not yet been attained.

There are just one or two points I would like to mention, if I may, before I throw it open to discussion. The first is about the question of bleeding. Now, I don't think that this should arise at all if the operation is carried out in the classical way. If the area that is about to be divided is first coagulated with the electrode and then divided with a Collins knife-no loop at all (I think the loop's a mistake)-bleeding is minimal, and I think Mr. Gibbon will bear me out that we've had no trouble with this for many years. Our first report did report bleeding, because mistakenly we used the punch for the first three or four cases, and it proved a mistake for it caused a lot of bleeding. However, by using the simple technique I've just mentioned, the bleeding is trivial. The extent of the cuts we have carried out veru montanum downwards for about $\mathrm{I} \cdot 5 \mathrm{~cm}$. I just want to remind our Geneva colleagues that reports on the follow-up of cases have been available since I 956 and we've always pointed out that these are followed up once a year and that sometimes it is necessary to repeat the operation. In fact it's better to do too little on the first occasion rather than too much.

I was very interested in Dr. Perkash's paper on the I2 o'clock division. Many, many years ago-Sir Ludwig will remember this-Bors, when he was describing the external sphincter, pointed out that there was an aggregation of striated fibres at 12 o'clock in the anterior commissure and this may well be the reason for the very successful results which obviously followed that division. Now, conversely, everything is rather thin there, and I've always been rather worried and concerned about whether or not some complication might arise.

Those were the only points. I would like to ask Dr. Dollfus whether he thinks that the absence of erections is permanent and whether he thinks that the psychological factors are important. And the other plea I would make is that, obviously the last word has not been said on the structure and the function of the external sphincter, and it does require a considerable amount of further study I think before we reach the final truth.

It is now open to discussion.

Dr. Rozin (Israel). I would like to ask Dr. Thomas how large is the percentage of loss of erections? This is very important to know as we now have well-informed patients who sometimes refuse external sphincter resection because of the information they have regarding loss of erections, although transurethral may be indicated.

DR. ThOMAs (G.B.). I simply can't explain the difference in results. The surgery 